Committee on Manuscript Collections Standards Subcommittee (ad hoc)

"Monday, January 18, 10:00 a.m.12:00 noon

Committee on Manuscript Collections Work Manual Subcommittee (ad hoc)

* Monday, January 18, 10:00 a.m.-12:00 noon

Subject Specialist Section

Executive Committee

"Monday, January 18, 4:30-6:00 p.m.

Agricultural and Brological Sciences

SUBSEction

Executive Committee

${ }^{*}$ Wednesday, January 20, 8:00-9:30

a.m.

Art Subsection

Executive Committee

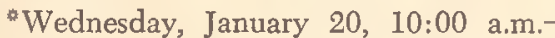

12:00 noon

Education and Behavioral Science SubSECTION

Executive Committee

"Friday, January 22, 8:00-9:30 a.m.

Slavic and East European Subsection

Executive Committee

"Friday, January 22, 2:00-4:00 p.m.

UNIVERSITY LiBRaRIES SECTION

Steering Committee (Executive Committee)

"Wednesday, January 20, 4:30-6:00

p.m.

Committee on Extension Library

Thursday, January 21, 4:30-6:00 p.m.

Urban UnIVERSITIES LIBRARY COMMITTEE

*Thursday, January 21, 10:00 a.m.-

12:00 noon

\section{ACRL NEEDS YOU!}

The ACRL Appointments and Nominations Committee is requesting the assistance of all ACRL members in providing names of ACRL members who might wish to serve on committees. Persons serving on committees must be willing to provide the time necessary to assume responsibilities resulting from such assignments, attend both the Midwinter and Annual Conferences, and answer correspondence promptly. Suggestions should include full name, complete address, committees to which a person might be appointed, and applicable background for such appointment. The Committee members are especially interested in securing names of individuals who have not previously been appointed to ACRL committees. Suggestions should be forwarded to George M. Bailey (Chairman), Chief Librarian, York College, 158-11 Jewel Ave., Flushing, N.Y. 11365.

\section{ALA AWARDS 1971}

American Library Association awards, citations, and scholarships are presented for distinguished service to the profession, publication, study, and research. Most of the 1971 awards will be made during the Dallas Conference. ALA members are urged to recommend candidates for the following awards. The chairman of the 1970-71 Awards Committee is Spencer G. Shaw, School of Librarianship, University of Washington, Seattle. Following is a list of awards of direct concern to members of ACRL with names of persons to whom nominations should be sent:

ala Scholarship Program. ALA Scholarship Program, approved by the ALA Council, January, 1969, provides scholarships, in the amount of $\$ 2500$, to be given annually to worthy students to begin and/or further their library education at the graduate level without regard to race, creed, color, or national origin. The recipients must enter a formal program of graduate study leading to a degree or advanced certificate at an ALA accredited school. As many scholarships as possible will be awarded, depending upon the total amount of contributed funds. The award may be withheld in any year when there are no worthy recipients. Administered by ALA Awards Committee and the Library Education Division. Application and recommendation forms are available from the jury chairman. Applications must be submitted by January 10, 1971. Chairman J. Phillip Immroth, Graduate School of Library and Information Sciences, University of Pittsburgh, Pittsburgh, Pa. 15213. Staff Liaison, Delores Vaughan.

Francis Joseph Campeell Citation. An annual award, consisting of a citation and medal, presented to a person who has made an outstanding contribution to the advancement of library service for the blind. This contribution may take the form of an imaginative and constructive program in a particular library; a recognized contribution to the national library program for blind persons; creative participation in library associations or blind organizations which advance reading for the blind; a significant publication or writing in the field; imaginative contribution to library administration, reference, circulation, selections, acquisitions, or technical services, or any activity of recognized importance. Donated and adminis. tered by Round Table on Library Service to the Blind. Deadline for nominations, January 15, 1971. Send nominations to jury chairman (to be appointed). Staff Liaison, Ira Phillips, ALA Headquarters. 